\title{
Determination of the composition of steels by inductively coupled plasma optical emission spectrometry (ICP-OES) using the Thermo Scientific iCAP 6500 Duo spectrometer
}

\author{
Andriy GRYTSKIV ${ }^{1}$, Yaroslav GRYTSKIV ${ }^{1}$, Anatoliy TROFYMCHUK ${ }^{2 *}$ \\ ${ }^{1}$ E.O. Paton Institute of Electric Welding, Bozhenko St. 11, 03680 Kyiv, Ukraine \\ ${ }^{2}$ Taras Shevchenko National University of Kyiv, Volodymyrska St. 61, 01033 Kyiv, Ukraine \\ * Corresponding author. Tel.: +380-44-2393273; e-mail: aktrof@ svitonline.com
}

Received November 1, 2009; accepted December 23, 2009; available on-line April 27, 2010

The aim of this work was to develop a procedure for analyzing steel products with a sampling of up to $0.5 \mathrm{~g}$ using an inductively coupled plasma optical emission spectrometer (ICP-OES). The procedure was checked by analyzing chips taken from standard samples belonging to industrial marks of steel. The results obtained by ICP atomic emission spectroscopy were compared with the results obtained using a spark spectrometer. The developed procedure was applied to determine the chemical compositions of chips taken from different parts of the supporting frame of a truck crane.

Inductively coupled plasma spectrometers / Analysis of steel products / Analytical characteristics

A great number of procedures have been developed and today a wide assortment of special analytical equipment for the analysis of chemical compositions of metal and alloys, including those widely spread and industrially produced, exists [1]. However, new analytical tasks for the control of steel products, or for individual parts made from them, constantly appear, and it is sometimes difficult to choose the appropriate method and device for the analysis. Very often complications appear when it is necessary to test a finished product, which must be left in for further use. The analysis must then be performed, or the sample taken, in such a way that the object does not loose its technical assignment or demand future restoration or repair. In addition, the more important and the more expensive the object, the less damage there must be and, at the same time, the more accurate the analysis must be. As a rule, these two conditions contradict each other. The list of objects requiring strict control of their composition is long: boilers, which operate under high pressure, and supplementary equipment; tanks for keeping fuel, lubricants and flammable materials; load-lifting or transportation mechanisms, cranes, and so on [2].

It is known that non-destructive control of the composition can be conducted by X-ray analysis and portable compact analyzers have been created for performing analyses under field conditions. Based purely on physical features, X-ray fluorescence analysis is realized in high-quality laboratories. X-ray fluorescence spectrometers are, however, expensive and sensitive enough only for the analysis of chemical elements heavier than sodium. The analysis by this method of the main steel additive carbon, or of alloying boron, commonly present in small amounts in recent steels, is practically impossible. The control of the content of sulfur and phosphor contaminating steel is hindered by the high uncertainty due to their small concentration; the upper limit is $0.020-0.030 \mathrm{wt}$.\% [3].

In this aspect, the portable optical emission spectrometers have slightly better analytical capability. The technical possibilities of these spectrometers have become significantly better over the last years. However, the analytical lines in vacuum ultraviolet, the most sensitive ones for the analysis of such elements as $\mathrm{C}, \mathrm{B}, \mathrm{S}, \mathrm{P}, \mathrm{As}, \mathrm{Al}$, or $\mathrm{Si}$, are inaccessible for portable emission spectrometers. Therefore, these devices are limited to analyzers for rough recognition and grading of known marks of steel [4].

To the above mentioned problems we must add complications connected with the type and form of the sample when mobile analyzers are used. Mobile analyzers generally require flat surfaces of determined size for the measurements, which is not always possible [5].

In connection to the above said, there exists, what we consider being a perspective method of analysis for steel products with sampling of a mass of $\sim 0.5 \mathrm{~g}$, inductively coupled plasma optical emission 
spectrometry (ICP-OES). The aim of this work was to develop a procedure analyzing steels by ICP-OES with the use of a spectrometer iCAP 6500 Duo produced by the firm Thermo Electron Corporation (USA). This spectrometer has a semi-conductor with a massif of 291,600 individually addressed lightsensitive pixels in the form of two-dimensional massifs of 540x540 elements covering a spectrum registered as $166.25-847 \mathrm{~nm}$. The method of reading the optical intensities gives the possibility to investigate materials with element concentrations ranging from $100 \%$ to traces.

The source of the atom excitations used for the analysis, inductively-coupled plasma, receives energy from a solid-body generator. The energy of the generator, which is regulated by steps (within $25 \mathrm{~W}$ ) ranges from 750 to $1350 \mathrm{~W}$ and can heat the plasma within the range 5,000-10,000 $\mathrm{K}$. This provides excitation of atoms and ions for any material composition. The device, completed by appropriate accommodations and transport systems, allows introducing into the plasma a sample solution with high acid or base content.

The software accompanying the spectrometer iCAP 6500 DUO takes into account the experience accumulated in the exploitation of former generations of ICP spectrometers. A number of options help in decreasing or avoiding the influence of many factors, such as instabilities of the experiment. This makes it possible to perform high-quality analyses and create new procedures that provide accurate results in particular situations.

The availability of an OES-ICP iCAP 6500 Duo spectrometer at the E.O. Paton Institute of Electric Welding (National Academy of Sciences of Ukraine) has motivated the elaboration of a procedure of analysis for a wide assortment of standard samples that are prototypes of different steel marks. Table 1 lists 37 standard steels containing certified concentrations of $\mathrm{C}, \mathrm{Si}, \mathrm{Mn}, \mathrm{S}, \mathrm{P}, \mathrm{Cr}, \mathrm{Ni}, \mathrm{Cu}, \mathrm{Mo}, \mathrm{V}$, $\mathrm{W}, \mathrm{Ti}, \mathrm{Al}, \mathrm{Co}, \mathrm{Nb}, \mathrm{As}, \mathrm{Pb}$ in an iron matrix. Each standard sample has its own characteristic collection of attested chemical elements.

Solutions of the standard samples were prepared in the following way: the sample, in the form of powder or chips $(0.100 \mathrm{~g})$ was transferred into a beaker flask $\left(100 \mathrm{~cm}^{3}\right)$ and was dissolved, under heating, in $10 \mathrm{~cm}^{3}$ of hydrochloric and nitric acids ("chemically pure", ratio 3:1). It was subsequently diluted with distilled water up to $1: 1$. After dissolution the solution was cooled and transferred into a volumetric flask of 100 $\mathrm{cm}^{3}$ capacity, diluted with distilled water and stirred.

For each solution the spectra of the elements listed above were measured and calibration plots for $\mathrm{Si}, \mathrm{Mn}$, $\mathrm{S}, \mathrm{P}, \mathrm{Cr}, \mathrm{Ni}, \mathrm{Cu}, \mathrm{Mo}, \mathrm{V}, \mathrm{Ni}, \mathrm{As}, \mathrm{Al}, \mathrm{Pb}, \mathrm{Co}$, as well as for $\mathrm{B}$ and $\mathrm{Se}$, were constructed with the software accompanying the device.

For each chemical element several spectral lines were tested. All lines were carefully investigated for suitability based on the following features: 1) absence of coincidence with the lines of other chemical elements, 2) oscillation of the background around the line, 3) maximum correlation between the intensity of the line and the background, 4) the best concentration sensitivity. The calibration plots of the analytical lines with the best indices of incline and correlation coefficients were included in the analytical program.

In most cases the calibration plots show linear dependency with insignificant deviation from the curve of the individual standards, as can be seen for $\mathrm{Cr}$ and Mn (Figs. 1 and 2).

For some elements, e.g. Ti, S, and As, the plot of the standard exhibits significant dispersion, as can be seen in the calibration plot for titanium (Fig. 3). The reasons for the deviations differ for different chemical elements. In the case of titanium the correlation coefficient could be improved from 0.905 to 0.958 and the standard uncertainty decreased from 0.064 to 0.043 by taking into account the influence of the interference with Cr. For sulfur the dispersion of the points in the calibration plot is mainly due to the low concentration of this element: $0.008-0.030$ mass $\%$ (see Table 1).

We did not succeed in calibrating the plots for the qualitative analysis of tungsten, which is made more complicated by the great variation of the experimental values during its determination. The reason for this turned out to be a non-additive solution of this chemical element during the procedure selected for the sampling.

Analytical characteristics of the procedure developed here are given in Table 2. The procedure was checked by performing a comparative analysis of chips of selected samples of steel. We compared the results of the investigation of these samples by the ICP atomic emission method with the results of investigations of the same samples by the spark atomic emission method using the spectrometer "Spectrovac-1000", produced by the firm BAIRD (see Table 3). The investigated samples belong to industrial marks of steels: 6XB2C (GOST 5950-73), 10ХСНД (GOST 19281-89), 30ХГC (GOST 4543-71).

The procedure developed this way was then used to determine the chemical composition of chips taken from different parts of the supporting frame of a truck crane produced in USA (Table 4). The samples listed in the table are numbered according to the order of their sampling and analysis, however, samples with similar contents of chemical elements have been grouped together. We managed to subdivide the samples into three groups; each group corresponds to a distinct steel mark as deduced from the chemical composition. All three steels distinguished based on the chemical composition belong to low-alloyed chrome-manganese-molybdenum constructive steel. The first of them (samples 1, 3,6) is close to the steel 25ХГМ GOST 4543-71; the two other steels do not have close analogues among common steels in Ukraine. 
Table 1 Maximum content of elements in standard steels, mass $\%$.

\begin{tabular}{|c|c|c|c|c|c|c|c|c|c|c|c|c|c|c|}
\hline $\begin{array}{c}\text { Element } \rightarrow \\
\text { Standard } \downarrow\end{array}$ & C & $\mathbf{S i}$ & Mn & $\mathbf{S}$ & $\mathbf{P}$ & $\mathrm{Cr}$ & $\mathbf{N i}$ & $\mathrm{Cu}$ & Mo & $\mathbf{V}$ & $\mathbf{W}$ & $\mathbf{T i}$ & Al & As \\
\hline $7 \mathrm{e}$ & -- & -- & -- & -- & 0.024 & -- & -- & -- & -- & -- & -- & -- & -- & -- \\
\hline 103 & -- & -- & 0.69 & -- & -- & -- & -- & -- & -- & -- & -- & -- & -- & -- \\
\hline $10 y$ & -- & -- & 0.653 & -- & -- & -- & -- & -- & -- & -- & -- & -- & -- & -- \\
\hline $20 \mathrm{~B}$ & 0.38 & 0.15 & 0.55 & 0.051 & 0.040 & 0.12 & 0.12 & -- & -- & -- & -- & -- & -- & -- \\
\hline $20 \Phi$ & 0.458 & 0.242 & 0.586 & 0.0258 & 0.0156 & 0.182 & 0.103 & 0.156 & -- & -- & -- & -- & -- & -- \\
\hline $26 \mathrm{~B}$ & 0.75 & 0.036 & 0.15 & 0.031 & 0.036 & 4.04 & 0.26 & 0.36 & -- & 1.17 & 17.23 & -- & -- & -- \\
\hline $27 \mathrm{a}$ & 0.74 & 0.44 & 0.38 & 0.024 & 0.025 & 3.74 & -- & 0.16 & -- & -- & -- & -- & -- & -- \\
\hline 28 б & 0.10 & 0.23 & 0.35 & 0.011 & 0.015 & 0.80 & 3.09 & 0.06 & 0.01 & -- & -- & 0.01 & -- & 0.01 \\
\hline 28 Г & 0.14 & 0.24 & 0.54 & 0.024 & 0.024 & 0.83 & 2.89 & 0.275 & 0.04 & -- & -- & 0.002 & -- & 0.01 \\
\hline 30 и & 0.20 & 0.24 & 0.46 & 0.013 & 0.013 & 0.92 & 4.06 & 0.074 & -- & 0.23 & -- & -- & -- & -- \\
\hline 31 e & 0.33 & 0.224 & 0.66 & 0.012 & 0.018 & 0.98 & 2.78 & 0.19 & 0.27 & -- & -- & -- & -- & -- \\
\hline 33 б & 1.02 & 0.28 & 0.37 & 0.012 & 0.016 & 1.61 & 0.13 & 0.17 & -- & 0.03 & -- & -- & -- & 0.02 \\
\hline 84 и & 0.41 & 0.28 & 0.77 & 0.031 & 0.059 & -- & -- & -- & -- & -- & -- & -- & -- & -- \\
\hline 85 и & 0.13 & 0.298 & 0.775 & 0.125 & 0.115 & -- & -- & -- & -- & -- & -- & -- & -- & -- \\
\hline 86 б & 0.38 & 0.18 & 0.455 & 0.018 & 0.019 & 1.52 & 0.11 & 0.20 & 0.17 & 0.02 & -- & 0.007 & 0.72 & 0.01 \\
\hline 116 & 0.36 & 1.17 & 1.43 & 0.009 & 0.022 & 0.21 & 1.0 & 0.14 & -- & 0.02 & -- & 0.002 & -- & -- \\
\hline 117 & 0.3 & 1.61 & 1.48 & 0.013 & 0.024 & 0.15 & 0.04 & 0.08 & 0.21 & 0.02 & -- & -- & -- & 0.01 \\
\hline 122 б & 0.88 & 0.24 & 0.20 & 0.017 & 0.021 & 4.13 & 0.20 & -- & -- & 2.14 & 9.32 & -- & -- & -- \\
\hline 122 д & 0.912 & 0.162 & 0.252 & 0.016 & 0.028 & 4.09 & 0.208 & -- & 0.353 & 2.38 & 9.64 & -- & -- & -- \\
\hline 126 Г & 0.015 & 0.005 & 0.021 & 0.026 & 0.003 & 0.046 & 0.15 & 0.21 & -- & 0.003 & -- & -- & -- & 0.024 \\
\hline $127 \Gamma$ & 0.17 & 0.32 & 1.22 & 0.009 & 0.020 & 1.64 & 0.063 & -- & -- & -- & -- & 0.028 & -- & -- \\
\hline 145 & 0.97 & 0.34 & 1.0 & 0.009 & 0.033 & 1.0 & 0.21 & 0.08 & 0.08 & 0.02 & 1.57 & -- & -- & 0.01 \\
\hline 150 & 0.14 & 0.32 & 0.83 & 0.17 & 0.167 & 0.24 & 0.15 & 0.13 & -- & 0.09 & -- & -- & -- & 0.01 \\
\hline 151 & 0.18 & 0.31 & 0.53 & 0.014 & 0.017 & 0.89 & 0.14 & 0.23 & 0.05 & 0.03 & -- & 0.02 & -- & 0.02 \\
\hline 155 B & 0.10 & 4.18 & 0.13 & 0.004 & 0.016 & 0.11 & -- & 0.18 & -- & -- & -- & -- & 0.057 & -- \\
\hline 156 & 0.79 & 0.30 & 0.34 & 0.014 & 0.028 & 4.66 & 0.28 & 0.15 & 0.51 & 1.5 & 17.06 & 0.005 & Co- 10.5 & 0.03 \\
\hline $213 a$ & -- & -- & -- & -- & -- & -- & -- & -- & -- & -- & -- & -- & 0.146 & -- \\
\hline 303 a & 0.057 & 0.292 & 0.647 & 0.007 & 0.017 & 0.634 & 1.49 & 0.194 & -- & -- & 0.533 & -- & -- & -- \\
\hline 324 a & 0.278 & 1.11 & 0.687 & 0.0082 & 0.016 & 2.96 & 1.03 & 0.13 & 0.408 & 0.11 & 1.03 & -- & -- & -- \\
\hline C 3 б & 0.087 & 0.0058 & 0.393 & 0.028 & 0.0109 & 0.033 & 0.041 & 0.033 & 0.0006 & -- & -- & -- & -- & 0.0017 \\
\hline C 4 б & 0.117 & 0.218 & 0.891 & 0.130 & 0.105 & 0.077 & 0.098 & 0.136 & -- & -- & -- & -- & -- & -- \\
\hline C 7 a & 0.346 & 0.33 & 0.698 & 0.0164 & 0.0205 & 0.033 & 0.036 & 0.034 & -- & 0.007 & -- & -- & 0.0083 & -- \\
\hline С 8 б & 0.734 & 0.218 & 0.855 & 0.0255 & 0.0211 & 0.023 & 0.055 & 0.037 & -- & -- & -- & -- & -- & 0.122 \\
\hline С 28 б & 0.481 & 0.826 & 0.211 & 0.0047 & 0.0148 & 5.93 & 0.725 & 0.113 & 0.617 & 0.612 & 3.76 & -- & 1.63 & Co-0.012 \\
\hline C 50 a & 0.096 & 0.283 & 1.27 & 0.0084 & 0.0073 & -- & -- & -- & -- & 0.08 & -- & -- & 0.018 & 0.0034 \\
\hline У 2 & 0.138 & 0.083 & 1.123 & 0.266 & 0.050 & 0.148 & 0.315 & 0.143 & -- & -- & -- & -- & -- & $\mathrm{Pb}-0.288$ \\
\hline У 4 & 0.418 & 0.151 & 0.559 & 0.045 & 0.026 & 0.24 & 0.09 & 0.14 & -- & -- & -- & -- & -- & 0.0079 \\
\hline
\end{tabular}


A. Grytskiv et al., Determination of the composition of steels by inductively coupled plasma ...

Table 2 Analytical characteristics of IPC-OES for different analytical lines, $\mathrm{nm}$.

\begin{tabular}{|c|c|c|c|c|c|c|c|c|c|c|c|c|c|c|c|c|}
\hline $\begin{array}{c}\text { Element } \rightarrow \\
\text { Indices } \downarrow\end{array}$ & $\begin{array}{c}\text { Al } \\
396.1\end{array}$ & $\begin{array}{c}\text { As } \\
193.7 \\
\end{array}$ & $\begin{array}{c}\text { B } \\
208.9 \\
\end{array}$ & $\begin{array}{c}\text { Co } \\
228.6 \\
\end{array}$ & $\begin{array}{c}\mathrm{Cr} \\
267.7 \\
\end{array}$ & $\begin{array}{c}\mathrm{Cu} \\
324.7 \\
\end{array}$ & $\begin{array}{c}\text { Mn } \\
257.6 \\
\end{array}$ & \begin{tabular}{|c} 
Mo \\
202.0 \\
\end{tabular} & $\begin{array}{c}\mathrm{Ni} \\
216.5\end{array}$ & $\begin{array}{c}\mathbf{P} \\
177.4 \\
\end{array}$ & $\begin{array}{c}\mathbf{P b} \\
220.3 \\
\end{array}$ & $\begin{array}{c}S \\
182.0 \\
\end{array}$ & $\begin{array}{c}\text { Se } \\
196.0 \\
\end{array}$ & $\begin{array}{c}\mathrm{Si} \\
212.4\end{array}$ & $\begin{array}{c}\text { Ti } \\
334.9 \\
\end{array}$ & $\begin{array}{c}\mathrm{V} \\
309.3 \\
\end{array}$ \\
\hline $\begin{array}{l}\text { Limit of conc., } \\
\text { mass } \%\end{array}$ & $\begin{array}{c}0.008- \\
1.6 \\
\end{array}$ & \begin{tabular}{|r|}
0.0034 \\
-0.122 \\
\end{tabular} & $\begin{array}{c}0.001- \\
0.02 \\
\end{array}$ & $\begin{array}{c}0.012- \\
10.5 \\
\end{array}$ & $\begin{array}{c}0.023- \\
5.93 \\
\end{array}$ & $\begin{array}{c}0.033- \\
0.36 \\
\end{array}$ & $\begin{array}{c}0.021- \\
1.48 \\
\end{array}$ & $\begin{array}{l}0.0006 \\
-0.61 \\
\end{array}$ & $\begin{array}{c}0.036- \\
4.06 \\
\end{array}$ & $\begin{array}{r}0.0073 \\
-0.115 \\
\end{array}$ & $\begin{array}{r}0.00024 \\
-0.288 \\
\end{array}$ & $\begin{array}{l}0.004- \\
0.266 \\
\end{array}$ & \begin{tabular}{|l|}
$0.02-$ \\
0.20 \\
\end{tabular} & $\begin{array}{l}0.005- \\
4.18 \\
\end{array}$ & $\begin{array}{l}0.002- \\
0.028 \\
\end{array}$ & $\begin{array}{c}0.007- \\
2.38 \\
\end{array}$ \\
\hline $\begin{array}{l}\text { Number of used } \\
\text { standards }\end{array}$ & 6 & 7 & 3 & 2 & 25 & 24 & 32 & 9 & 27 & 18 & 2 & 15 & 3 & 30 & 6 & 13 \\
\hline $\begin{array}{l}\text { Slope of the } \\
\text { calibration plot }\end{array}$ & 2.24 & 9.44 & 57.95 & 221.6 & 3.21 & 5.47 & 15.86 & 103.7 & 155.4 & 3.26 & 32.54 & 4.97 & 9.44 & 25.16 & 27.80 & 9.93 \\
\hline $\begin{array}{l}\text { Coefficient of } \\
\text { correlation }\end{array}$ & 0.999 & 0.988 & 0.999 & 1.00 & 0.997 & 0.998 & 0.993 & 0.998 & 0.999 & 0.990 & 1.00 & 0.993 & 0.999 & 0.998 & 0.958 & 0.998 \\
\hline
\end{tabular}

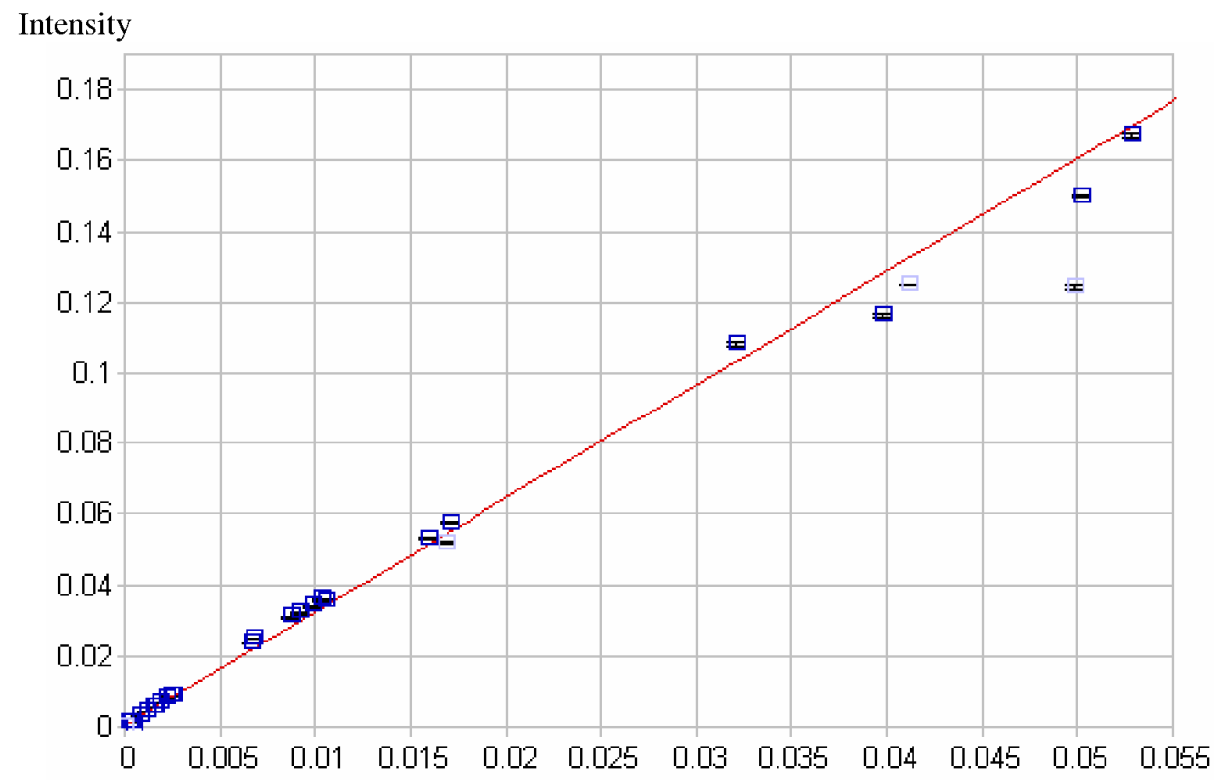

Fig. 1 Calibration plot for the $\mathrm{Cr}$ analytical line at $267.715 \mathrm{~nm}$.

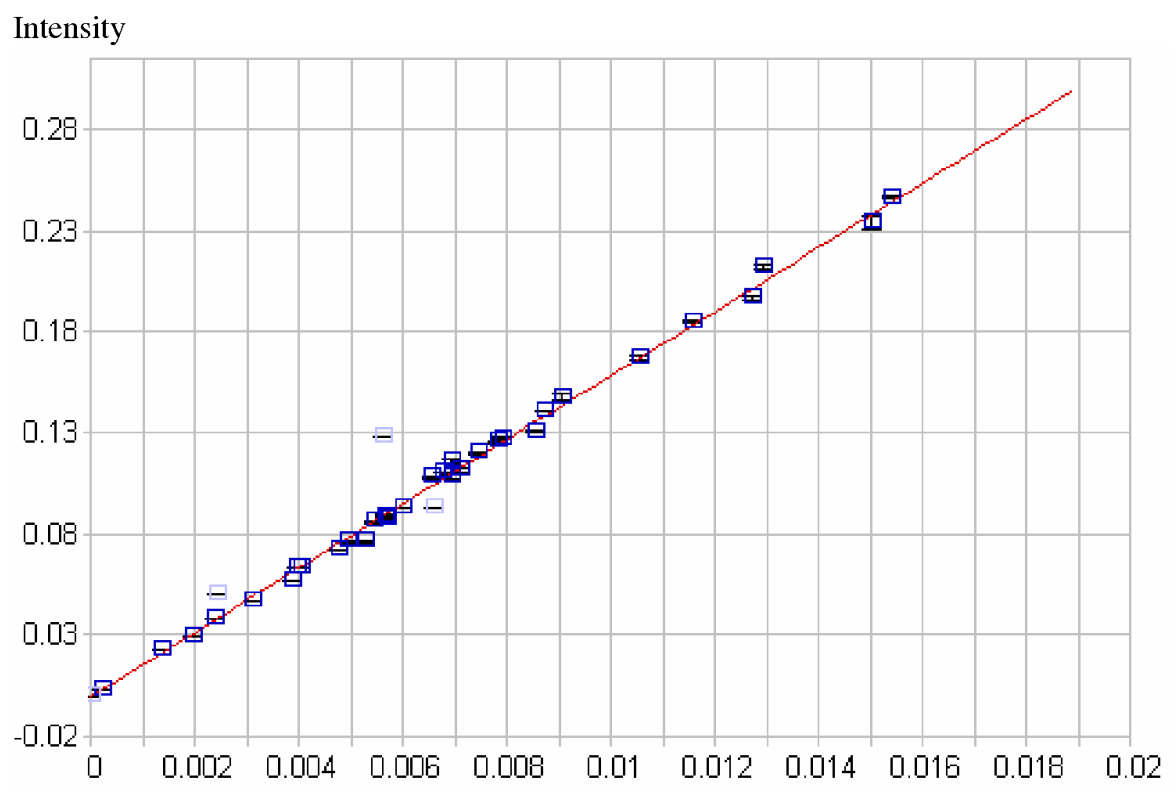

Fig. 2 Calibration plot for the Mn analytical line at $257.610 \mathrm{~nm}$. 


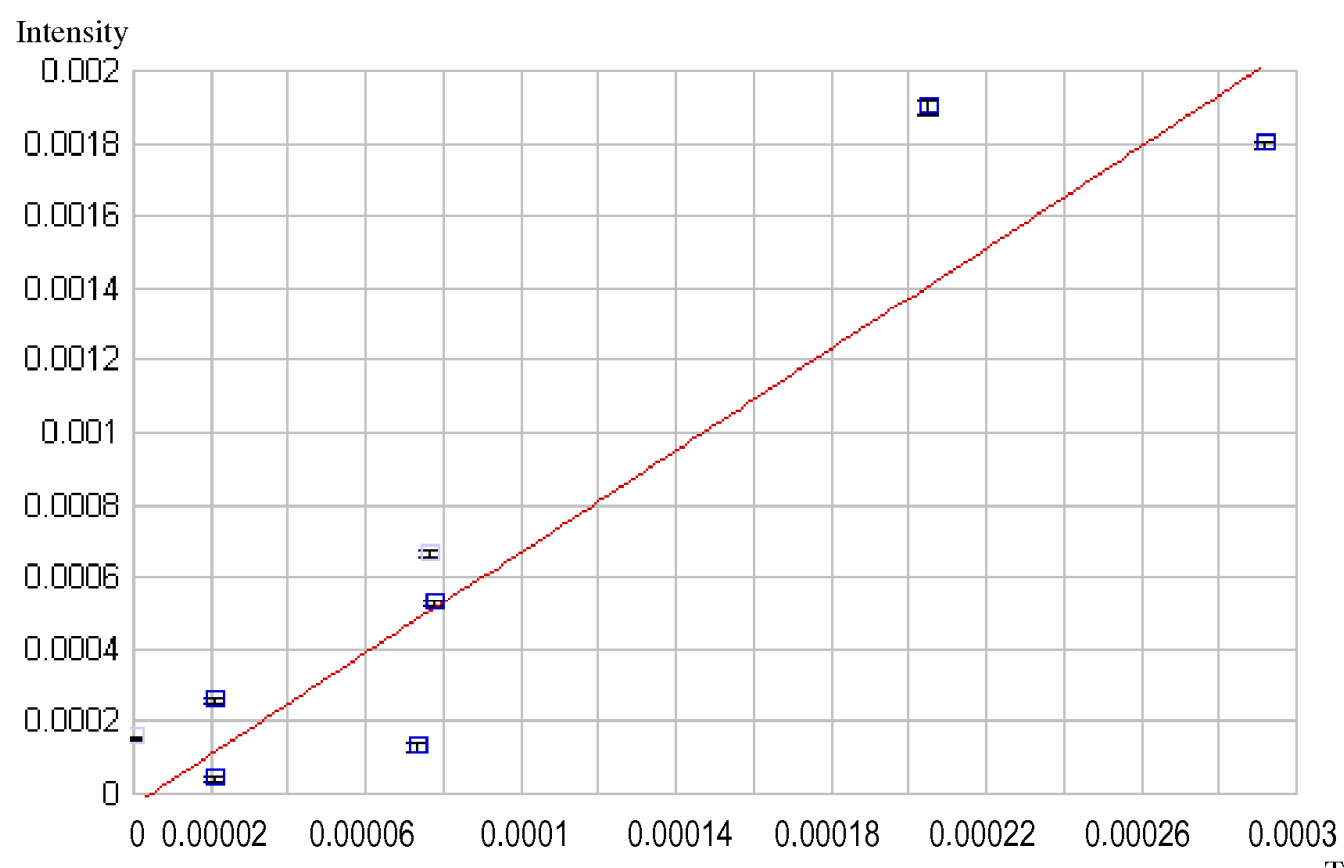

Ti concentration

Fig. 3 Calibration plot for the Ti analytical line at $334.904 \mathrm{~nm}$.

Table 3 Comparative analysis of the concentration of chemical elements in standard steels, mass $\%$.

\begin{tabular}{|c|c|c|c|c|c|c|c|c|c|c|c|c|c|c|}
\hline $\begin{array}{c}\text { Element } \rightarrow \\
\text { Sample } \downarrow\end{array}$ & $\mathrm{C}$ & Si & Mn & $\mathbf{S}$ & $\mathbf{P}$ & $\mathrm{Cr}$ & $\mathbf{N i}$ & Mo & $\mathbf{V}$ & $\mathrm{Cu}$ & Al & Co & W & \\
\hline \multirow{2}{*}{$6 \times B 2 C$} & 0.56 & 0.64 & 0.33 & 0.019 & 0.024 & 1.18 & 0.16 & 0.04 & $\mid<0.02$ & 0.12 & 0.019 & 0.015 & \multicolumn{2}{|c|}{2.21} \\
\hline & & 0.60 & 0.31 & 0.020 & 0.029 & 1.25 & 0.16 & 0.03 & 0.018 & 0.13 & 0.020 & 0.014 & & \\
\hline \multirow{2}{*}{ 10ХСНД } & 0.115 & 1.08 & 0.73 & 0.025 & 0.029 & 0.92 & 0.59 & $<0.03$ & $<0.02$ & 0.42 & -- & & \multirow{2}{*}{\multicolumn{2}{|c|}{$\begin{array}{ll}-- & \\
---\end{array}$}} \\
\hline & & 1.01 & 0.71 & 0.016 & 0.030 & 0.95 & 0.58 & 0.006 & 0.010 & 0.43 & 0.035 & 0.011 & & \\
\hline \multirow{2}{*}{ 30XГС } & 0.31 & 1.11 & 0.96 & 0.020 & 0.025 & 0.93 & 0.11 & $<0.03$ & $<0.02$ & 0.10 & 0.020 & & \multirow{2}{*}{\multicolumn{2}{|c|}{4}} \\
\hline & & 1.04 & 0.93 & $\begin{array}{ll}3 & 0.010\end{array}$ & 0.024 & 0.99 & 0.10 & 0.006 & 0.014 & 0.10 & 0.013 & 0.004 & & \\
\hline
\end{tabular}

- In the upper left corner the results obtained on the spark spectrometer "Spectrovac-1000" are given.

- In the lower right corner the results obtained on the ICP spectrometer iCAP 6500 Duo are given.

- --- results are absent.

Table 4 Results of the analysis of the chemical composition of individual parts of the supporting frame of a crane.

\begin{tabular}{c|c|c|c|c|c|c|c|c|c|c}
\hline $\begin{array}{c}\text { Element } \rightarrow \\
\text { Sample } \downarrow\end{array}$ & Si & Mn & $\mathbf{S}$ & $\mathbf{P}$ & $\mathbf{C r}$ & $\mathbf{N i}$ & $\mathbf{M o}$ & $\mathbf{V}$ & $\mathbf{C u}$ & $\mathbf{T i}$ \\
\hline 1 & 0.35 & 0.95 & 0.012 & 0.014 & 1.47 & 0.03 & 0.44 & $<0.01$ & 0.03 & 0.031 \\
3 & 0.35 & 0.96 & 0.040 & 0.013 & 1.50 & 0.03 & 0.44 & $<0.01$ & 0.03 & 0.034 \\
6 & 0.35 & 1.01 & 0.029 & 0.013 & 1.49 & 0.03 & 0.43 & $<0.01$ & 0.04 & 0.042 \\
2 & 0.40 & 1.49 & 0.009 & 0.016 & 0.59 & 0.02 & 0.31 & 0.0095 & 0.03 & 0.035 \\
4 & 0.41 & 1.51 & 0.014 & 0.015 & 0.60 & 0.02 & 0.30 & $<0.01$ & 0.03 & 0.035 \\
7 & 0.40 & 1.55 & 0.007 & 0.015 & 0.61 & 0.02 & 0.31 & $<0.01$ & 0.03 & 0.036 \\
9 & 0.41 & 1.58 & 0.002 & 0.017 & 0.62 & 0.02 & 0.31 & $<0.01$ & 0.03 & 0.036 \\
5 & 0.23 & 1.41 & 0.002 & 0.017 & 0.51 & 0.02 & 0.26 & $<0.01$ & 0.12 & 0.030 \\
8 & 0.23 & 1.43 & 0.002 & 0.016 & 0.51 & 0.02 & 0.26 & $<0.01$ & 0.13 & 0.031 \\
\hline
\end{tabular}


The concentrations of the chemical elements, both of volatile $(\mathrm{Cr}, \mathrm{Mn}, \mathrm{Mo})$ and finish-mixing $(\mathrm{P}, \mathrm{Ni}, \mathrm{Cu}$, $\mathrm{V}, \mathrm{Ti}$ ) elements, in the samples of one group are so close to each other that it is possible to assert the belonging of the samples to the same melt and supply. Deviations in the concentration of sulfur among the samples of the same group seem to indicate the presence of dye traces in the chips due to improper cleaning before drilling.

The results confirm the high quality of the analysis, the high sensitivity of the spectrometer and its stability during the operations, and the usefulness of the procedure for practical applications.

\section{References}

[1] N.G. Farzane, L.V. Ilyasov, A.Yu. Azim-Zade, Technological measurements and devices, Visshaya Shkola, Moscow, 1989, $456 \mathrm{p}$ (in Russian).

[2] I.P. Alimarin, V.M. Ivanov, Practical handbook on physical-chemical methods of analysis, Izd. MGU, Moscow, 203 p (in Russian).

[3] L.V. Vilkov, Yu.A. Pentin, Physical methods of investigation in chemistry. Structural methods and optical spetroscopy, Visshaya Shkola, Moscow, 1987, 366 p (in Russian).

[4] Application of ICP to emission spectroscopy, R.M. Barners (Ed.), Franklin Inst. Press, Philadelphia, 1978, $169 \mathrm{p}$.

[5] V.P. Zamareyev, N.I. Gulko, L.I. Kharlamova, I.A. Vasina, Automated methods of metal tests, Metallurgia, Moscow 1982, 310 p (in Russian). 